\title{
An Appraisal of the Language of Art: the Oral Narratives Examples
}

\author{
Uche Nnyagu $\mathrm{PhD}^{*}$ \\ Department of English, Nnamdi Azikiwe University, Awka \\ *Corresponding Author \\ Uche Nnyagu PhD
}

\section{Article History}

Received: 09.06.2020

Accepted: 16.06 .2020

Published: 25.06.2020

\begin{abstract}
Language is an indispensable tool for literature; without it, there can never be literature. Language and literature are inseparable as no story can be possible without language. Even in pantomime, language is still a major tool as the characters use sign language as they demonstrate. However, language of art, to a great extent, differs from ordinary language of speech. That being the case, good writers cum story tellers, are meticulous about their choice of language in their individual creative writings. A good writer first determines the genre he or she wants to write before selecting his or her language because the language apt in a particular genre may not be appropriate in another genre. An author's work is adjudged good or bad depending to a great extent on his or her language hence language makes a work interesting and otherwise. A particular author's work is either appreciated or loathed depending on his or her language. An author may have a very wonderful story to tell but if he or she fails to be mindful of his or her language, he or she would end up writing the kind of literature that would never be appreciated. In this paper therefore, the researcher's aim is to determine the languages apt for certain aspects of art with particular reference to tales. This, he believes, will help potential writers whose interests are in traditional tales to be able to use the appropriate language in their writings.
\end{abstract}

Keywords: Language, tales, Africa, raconteur, genre.

\section{INTRODUCTION}

Wikipedia Online Dictionary defines language as "a system that consists of the development, acquisition, maintenance and use of complex systems of communication, particularly the human ability to do so; and a language is any specific example of such a system."From this definition, we are able to infer that language concerns particularly the human beings who use language for communication. Human beings are distinguished from the lower animals basically because human beings reason and they use highly moderated language as a medium of communication. In the view of Nneka Umera-Okeke, language is a social phenomenon. She quotes Ferdinand de Saussure as saying that language use reflects the contemporary structure which should enable synchronic language analysis (in which languages are treated as self contained system of communication used at a given point in time) in addition to diachronic analysis (in which the change to which languages are subjected to in the course of time are treated historically) (7). Umera-Okeke maintains that the social aspect of using language, or speech was called parole (the linguistic competence of the speaker) by Saussure, while the underlying knowledge of linguistic structure was known as langue (the actual phenomenon or data of linguistic utterance)[1-5].

In both writing and speech, language is used to express culture. It is a fact universally acknowledged that when one speaks, one's identity or culture, to a great extent, is ascertained. Emmanuel Obiechina in his Language and Theme is aware of this undisputed fact and that is why he states categorically that when a people use a language other than their own language, part of their culture is eluded. He puts it vividly that writing in English presents the West African writer with a problem the English writer does not have. In his own language he postulates thus; "Stated simply, it is how to express the African experience in a language that was originally evolved to embody a different kind of experience and to convey a different kind of sensibility?" Lamenting that part of the beauty of African culture is lost when the African writers write in languages other than theirs, he succinctly puts it in apparent question. Thus, "How can the novelist render

Copyright @ 2020: This is an open-access article distributed under the terms of the Creative Commons Attribution license which permits unrestricted use, distribution, and reproduction in any medium for non commercial use (NonCommercial, or CC-BY-NC) provided the original author and source are credited. 
his characters' words, feelings, and attitudes in English and still retain their idiomatic quality and authenticity?” (53)[6, 7]. He goes further to emphasize that:

This, in a way, is the problem of all translations; but, for the West African writer, the problem is more immediate and acute than in ordinary cases of translations. To the West African living in one of the exBritish colonies, English is the nation, administrative, legal, and (along with the vernaculars), literary language. The writer using the English language is therefore bilingual and expected to be "at home" both in English and his own language (53).

\section{THEORETICAL FrAMEWORK}

The researchers believe that structural criticism is the apt theory for the research. This theory became prominent in the nineteenth century and it is used to analyze the quality of linguistics aspects of literary works. Ann B[8-10]. Dobie is of the view that structuralism is a twentieth century affair which emanated to have a significant impact on how people understand the world. She looks at it as a science that seeks to understand how systems work. This theory, Dobie says, accepts the belief that things cannot be understood individually, rather, they have to be seen as part of a larger structure (or aesthetics or meaning) of a single entity as they are trying to describe the underlying (and not necessarily visible) principles by which it exists. According to Abrams in A Glossary of Literary Terms, almost all literary theorists beginning from Aristotle have emphasized the importance of structure, conceived in diverse ways, in analyzing a work of literature (309). He describes structuralism as the practice of critics who analyze literature on explicit model of structuralist linguistics. Abrams' view that structuralism was used in 1950s and 1960s by Levi-Strauss and other writers goes to consolidate Dobie's claims as right. Other critics agree with Abrams and Dobie that structuralism is interested in the artist's linguistics. The fact that the present research is based on linguistic analysis of art is the researcher's major reason for opting for the theory as the most appropriate theory for the research[11].

\section{Oral Narratives}

The term, "oral" denotes the act of transmission of ideas, message, information and things of such not in written form but in oral means. Basically, Orality is the oldest means of communication; the ancient folk communicated in their ancient language not written. Today, the concept "oral literature" is disparaged as critics see the oxymoronic nature of the concept as impossibility. M. H. Abrams in A Glossary of Literary Terms, sees literature as coming from Latin word "litteraturae" which entails "writings". He discloses that literature has been commonly used since the eighteenth century, equivalently with the French belles letter ("fine letters"), to designate fictional and imaginative writings - poetry, prose fiction, and drama. His emphasis is that literature can only be written and attributing it to eighteenth century affair goes to consolidate his claims since the act of writing only emerged in the era. Also, Chris Baldrick in his Oxford Concise Dictionary of Literary Terms, believes that literature is that which is written. From the concepts of the scholars, it is palpable that they fail to recognize oral art as part of literature. They are of the view that since literature is that which is written down, it can never be orally transmitted as well. The critics and scholars failed to accept the usage of the phrase "oral literature" because of the juxtaposition of the two self seeming contradictory words. This accounts for why Pio Zirimu, an Ugandan scholar coined the word "orature" from "oral literature" to replace "oral literature. However, it is impossible to annihilate the phrase "oral literature" for it has come to stay. What the critics failed to put into consideration before rejecting "oral literature" is the fact that before one cannot write if the person had not conceived the story in his or her mind. In most cases, that which is conceived in the mind is first told to a physical or mental audience before being written down. In both speech and in writing, language is used. What is said orally can be written using the same language and in most cases, as has been said earlier, before one can write a story, one would first tell the story. This being the case, it is therefore, impossible to get rid of the term since a story written down had in the past, been relayed orally. So, the phrase "oral literature" is not out of place as perceived by scholars who are of the view that the phrase is self contradictory[12].

The term narrative on the other hand, denotes prose form. It is the form of presentation of a literary genre which takes the shape of prose and not poetic or dramatic. As Abrams puts it in his A Glossary of Literary Terms, "A narrative is a story, whether told in prose or verse, involving events, characters, and what the characters say and do" (181). He goes further to emphasize that some literary forms such as the novel and short story in prose, and the epic and romance in verse, are explicit narratives that are told by a narrator. In oral literature therefore, oral narratives stand as a subgenre synonymous with prose narratives or prose forms. According to F. B. O. Akporobaro, "a large number of oral literary forms are created in the language of ordinary prose" (45). Affirming that to an extent, prose narratives can admit some stylistic features associated with poetry, he vividly discloses that basically, narratives, stories, or sayings are in prose form and the artists who render them do not try to impose upon them the formal and stylistic features of metre, rhyme, and imagery, which we associate with poetry. He lists the most important prose forms to include: The folktale, Formal speeches, Epic, Legend, Myth, Proverb, Panegyric. These are the central focus of this paper. 


\section{The Language of Folktale}

Folktale is a fictional narrative rendered orally. Its setting is usually an imaginary rural area in the remote past when animals talked and reasoned like humans. Usually, much importance is not attached to the name of the place of action in folktales as many folktales simply give the picture of their setting as a faraway place. However, in Igbo, the setting is often referred to as Iduи na Oba. Akporobaro in his Introduction to African Oral Literature looks at folktale as one of the commonest and easily the most popular form of oral literary expression in many African societies (96). Folktale is told mainly for entertainment and for its didactic nature. The story of folktale is not meant to be believed because it has no historical reality. It is rather told to the children to help them build their moral life. This is why Akporobaro emphasizes that this aspect of literature is meant for entertainment and that is why it has remained alive even when it is not documented in writing. The raconteur of folktale first puts his or her language into consideration before telling the tales. Some people would listen to a particular folktale by a particular raconteur and would never enjoy the story but when the same story is told by another storyteller, the audience listen with rapt attention because the storyteller is gifted and his or her language is apt. Today, modern artists document folktales and other aspects of oral literature in written tradition. Uche Nnyagu's Lizard and Chameleon, J.N.J. Okafor's The Big Fish and F.C. Ogbalu's Mbediogu are good examples. Uche Nnyagu believes that if the language of folktale is trite, it would not be appreciated by the listeners. Therefore, in his "The Nature of Oral Literature" he encourages the storyteller in folktale to use appropriate language in telling his or her story so that his or her story would be appreciated by the listeners. According to him, language of folktale, is basically narrative, down to earth, inspiring and must cohere with the distant past setting of the tale (1153). In his Preface to Oral Literature, Okoh emphasizes on the importance of language in folktale. He is of the view that that the language of folktale is both narrative and dramatic. He makes it vivid in these words: "In other words, these forms not only reveal a concern with formal excellence, but also display several other stylistic, creative and linguistic characteristics." By this, Okoh is of the opinion that language and other elements are well integrated to have an acceptable tale. Affirming that language plays a very vital role in folktales, Okoh and other scholars state that a good raconteur uses appropriate language to present interesting folktales. They disclose that a good raconteur mimics various animals who are the major characters of their folktales. It has been stated somewhere in this paper that folktales present their major characters as animals. These animals talk, reason and behave normally as normal human beings. Therefore, in presenting each of the animals as characters, the story teller fantastically mimics the individual languages of each of the animals[11]. This act of mimicking the animals, critics believe, adds authenticity to the tale. Uche Nnyagu in his Literature and Literate observes that folktales teach moral lessons about life. He believes that folktales are meant especially to teach the young ones virtue. As he puts it, "Folktales encourage virtue and discourage vice." Based on this fact, he recommends that in order that folktale would effectively perform the required task of encouraging virtue and discouraging vice, the language of the storyteller must be very simple and down to earth else, as to be appreciated by the target audience (362).

\section{Formal Speeches and its Stylistics}

According to Akporobaro in Introduction to African Oral Literature, the formal speech is one of the more important contexts for imaginative self expression in many African societies. Akporobaro defines formal speech as the kind of speech which is usually delivered by an elder, or delegated good speakers to the hearing of people who have come together to discuss an important issue in the clan, family, town, tribe, etc (46). He discloses as a matter of fact, that the main purpose of the speech is either to persuade the audience to the acceptance of a view point or it may merely be to present some information or advance a discussion in a formal tone appropriate to the given occasion. The Wikipedia Online Dictionary looks at the formal speech as a preplanned speech delivered to an audience at a formal or professional event, business lectures and celebrations like weddings. While believing Wikipedia that formal speech could be preplanned, it is not always the case. Sometimes, formal speech is not preplanned but spontaneous. For instance, in a formal gathering, someone might be called up to address the gathering and he would stand before the audience to address them. Such speech, of course, isn't preplanned.

In formal speech, choice of language is usually one major thing the speaker considers paramount. Even though the speaker here tries to impress, he must not forget that the onus is on him to communicate. The major reason here is to inform so the speaker is mindful of his language. Akporobaro is of the view that formal speech often differs from ordinary speech and therefore, that the language must be embellished. As he puts it, "In terms of form and style, formal speech often differs from ordinary speech by its measured tone, rhythm, and effective use of such rhetorical figures of proverbs, and vivid images and witticism" the speaker in this occasion must know proverbs and more importantly, know how to apply the proverbs in natural context. In Igbo, proverb is believed to be the oil with which words are eaten. In a formal speech, the speaker is appraised based on how well he is able to punctuate his speech with adequate proverbs (46). In Chinua Achebe's Arrow of God for instance, the white man invites Ezeulu to his house purposely to make him warrant chief because of the traits he has noticed in him. Ezeulu decides to intimate his people about the invitation. He is a good speaker so also is Nwaka, one of the influential elders of Umuaro. Nwaka is already angry with Ezeulu for sending his son, Oduche to join the white man. Nwaka could not understand why Ezeulu the Chief Priest of Ulu should send his own son to join the new religion that has come to fight theirs for whom he is the Chief Priest. Embittered, Nwaka in his 
formal speech, bemoans Ezeulu. He uses appropriate proverbs in reminding the elders of Umuaro that Ezeulu has fetched the ant ridden faggot and therefore, should not complain about the visits of lizards to his place. He stresses again that the white man is like a leper whom when you offer a hand to him for a handshake, he would opt for an embrace. Nwaka is an orator; he speaks for some time and his speech remains appreciated albeit his speech may never be preplanned[13].

In order to convey a convincing or moving argument, critics prescribe special language use. According to Akporobaro, the speech must be concise and tightly focused around the topic of concern. On top of content, a smooth and confident delivery is necessary to maximize the impact that the words have. He recommends that public speakers should spend time beforehand editing and rehearsing their speech. Nkem Okoh also believes that formal speeches are elevated. In his Preface to Oral Literature, he is of the view that the speaker in a formal speech considers the status of his audience before determining the appropriate language to use. It has to be reiterated at this juncture, that a good speaker is aware that the essence of communication is to pass information across. If at the end of a long speech, majority of the listeners failed to understand the message because of the ambiguity of the language, then the goal of the speech is defeated. Therefore, in a formal speech, the speaker is mindful of his language. Generally, for the goal of speech to be accomplished, the speaker considers using apt language devoid of ambiguity of any sort. Proverbs are profusely used in formal speech but the speaker must ensure that the proverbs that he uses are apt and adequate to enhance understanding and appreciation. Above all, the language in formal speech must be such that coheres with the tradition and culture of the people to whom the speech is rendered. This is called decorum[6].

\section{Epic}

In their A Handbook to Literature, W. F. Addison and A. Hibbard describe epic as a long narrative poem presenting characters of high position in a series of adventures which form an organic whole through their relation to a central figure of heroic proportions and through their development of episodes important to the development of a nation or race (155). Akporobaro in Introduction to African Oral Literature, affirms that an epic is a long narrative and that the hero of the epic who is being celebrated for a great deed is usually protected by or even descended from gods; he performs superhuman exploits in battle or in marvelous voyages, often saving or founding a nation (47). Umeasiegbu believes that there are two major types of the epic: the literary and the oral. The former has a known author while the latter has no such acknowledged creator. The literary epic is 'frozen' in print as it were, but the oral (or traditional) epic is in oral circulation: that is, it is transmitted by word of mouth. Our concern here is on the traditional epic. An interesting thing about epic (Literary or traditional) is that its character is unique and greatly differs from other literary characters; he must be a superhuman being whose actions are greatly beyond what ordinary begins can achieve. Abrams in A Glossary of Literary Terms, says that the hero of the epic isn't just ordinary being for his actions are beyond ordinary. Rems Umeasiegbu in his Anukili Ugama, says that the heroic epic can be defined as a long narrative that recounts in a coherent manner the deeds of a legendary hero with human traits and with supernatural attributes that are set against a background of extraordinary events, within the framework of a certain time span and a certain stretch of space. Epic, as a matter of fact, is practically distinguished from other aspects of literature in almost all ramifications. The language of the epic greatly differs from that of the others. Abrams says that it is rendered in a formal and elevated style. He makes it vivid that an epic "is narrated in a ceremonial style which is deliberately distanced from ordinary speech and proportioned to the grandeur and formality of the heroic subject and architecture. Similarly, Thrall and Hibbard insist that the speech of the characters of the epic is distinctly formal (155). However formal the language of the epic is, Umeasiegbu believes that in oral epic, the gifted raconteur coins words and gets them integrated in his epic as long as it does not mar the medium of the epic. As Umeasiegbu puts it:

"Mr. Nwabunwanne (the story teller) used certain rich, old expressions so beloved of tradition bearers and old, knowledgeable people, especially men. He even coined words to describe the movement of leaves, sea waves, and falling houses. Whether or not such words do exist in Igbo, we cannot say. But we suspect he coined them from the sound made by the objects being described. We had to go back to him for clarifications (14).

He adds that Igbo heroic epic is replete with Igbo idioms and proverbs and unusual reversal of words and sentence patterns. Repetitions abound. Previous fieldwork indicates that a performer intentionally repeats certain portions or expressions in order, among other things, to regain his breath or remember the sequence of the story (14). As the epic story teller tells his tales incorporating proverbs and coined words, he must ensure he maintains decorum which is the main issue in epic. Decorum here entails that the chief character in epic is an elevated personality and not a commoner. As an elevated figure, he is expected to speak in an official language.

\section{Legend}

This is a narrative aspect of literature and like other aspects of oral literature, is handed from one generation to another generation via oral tradition. According to Thrall and Hibbard, it is a narrative or tradition handed down from the past. They believe that a legend unlike some other aspects of oral literature like myths and folktales, has more historical 
truth and perhaps has less supernatural attributes. Legends have historical reality and its authenticity can be traced. Some prominent people who had performed certain feats in the past constitute the major characters of the legend[4]. Writers or narrators of legend derive inspirations from the feats of the prominent figures. Akporobaro is of the opinion that as an aspect of oral literature, legend is handed through popular oral tradition, usually consisting of exaggerated or unrealistic account of some actually or possibly historical person or event. According to him:

The term in Europe was originally applied to accounts of sqints' lives, but is now applied chiefly to fanciful tales of warriors and other characters; or more run recently to those bodies of biographical rumour and embroidered anecdote surrounding dead film stars and politicians like Awolowo or Dr Azikiwe or local warriors (48).

From the submissions of the critics, legend is based on some historical figures. That being the case, the language of legend would be close to the natural language of discuss as it concerned the historical beings talked about. The historical figures would be mimicked in the literary art. However, as Akporobaro discloses that legend, although it has historical reality, is exaggerated, exaggeration thus would feature extensively. The narrator of the legend tries to use language similar to the language of the concerned figures but then, exaggerated. In telling or writing legend, the artist must understand that he or she would make research to ascertain the choice of language of the concerned so as not to present something contrary to the audience. It is obvious that exaggeration of diction is required but not to the extent of belying the real fact. The artist is subtle in juxtaposing the real language of the concerned with the necessary exaggeration of diction[5].

\section{Myth}

Folktales and myths look alike in many aspects: both of them are not based on any historical fact and they are passed down from one generation to another via oral tradition. Sometimes, they perform the same function - being didactic and they are brief and not long. Both the myth and folktale can make use of animals and the like as characters. However, while folktales use only animals as characters, myths make use of both natural and supernatural beings as the characters and the setting is both the earth and beyond. Akporobaro describes myth as a kind of story or rudimentary narrative sequence, normally traditional and synonymous, through which a given culture ratifies its social customs or accounts for the origins of human and natural phenomena, usually in supernatural or boldly imaginative terms. The major difference noticed between folktale and myth is that why folktale's major preoccupation is to teach the young ones moral lessons like extolling virtue and discouraging vice, myth simply aims to solve mystical problems and disclose the seemingly credible but fallacious origins of things such as the origin of life and death, why there is day and night, the origin of rainfall and dry season etc.

Like in the case of folktales, the raconteur in myth is mindful of his or her language; he or she should use highly emotive language in order to keep and sustain his or her audience. M. H. Abrams says that some myths are related to social rituals - set forms and procedures in sacred ceremonies. This being the case, apt language that coheres with the tradition is used. Veteran storytellers are aware that if their language isn't lively and active, his or her story becomes boring. Therefore, a good storyteller meticulously selects his or her language, embellished with apt proverbs to make his or her tale active and lively. It has been stated earlier in this paper that the same tale told by two different persons can be enjoyed differently depending on the storyteller's choice of language. If the language of one of the storytellers is boring, trite and not inspiring, his or her story would be boring and he whose language is dynamic would have his tale well appreciated. Again, if the storyteller understands that the essence of communication is to pass information, he or she must use appropriate language that suits his or her tale and must as well, be down to earth[8].

\section{Proverb}

Nkem Okoh writes that proverbs occupy a commanding position in the rhetorical arsenal of African cultures. He discloses that in virtually every African society, proverbs constitute a dominant device, whether in everyday conversion or more serious, formal talk. In terms of definition, Akporobaro defines it "as a short popular saying of unknown authorship, expressing some general truth or superstition" (49). Nkem Okoh further describes it as a pithy saying that expresses some fundamental truth of human life or experience, even if such truism is abstract (124). Chinua Achebe describes proverb as the oil with which words are eaten. This entails that proverb beautifies words and elders in Igbo in particular and Africa in general delight in using proverbs in conversation. Scholars disclose that proverbs originate from societies and gradually, they become widely accepted. Uche Nnyagu in his "The Nature of Oral Literature" makes this fact vivid when he discloses that elders in certain societies, especially rural areas coin proverbs using things prominent in such societies as objects of their proverbs. In riverine areas for instance, originated the proverb, "a patient fisherman eats fish caught in a hook". The proverb "Bat says it knows how ugly it is and that is why it comes out only at night" comes from the villages surrounded by forests. The animals used as objects of the proverbs have their reflections on individuals; the speaker or the listener. 
According to Nkem Okoh, the foremost feature of the proverb that merits consideration is its language. He says that "The language of the proverb is of an allusive, epigrammatic, codified, and above all, graphic nature; this especially recommends it a variety of discourse situations (124-125). For proverb to be effective, its language must be apt: the user of the proverb must not forget that proverbs are meant to advance knowledge and if ambiguous language is used, the beauty and aim of the proverb are lost. Okoh observes that proverb is an essential device for embellishing speech, a factor which derives directly from its especial use of language (125). He writes further that "Many critics will declare that literature is all about the creative or remarkable use of language.

Language of the proverb has to be simple and precise. Storyteller must understand that proverb, as Achebe puts it, is the oil with which words are eaten. This being the case, he or she must bear in mind that he or she does not use proverb to impress but to communicate and therefore, in order that he or she is understood, the language of his proverb must not be ambiguous. Proverb is well understood when it is effectively used in the right context. The objects of the proverb are simply what both the user and the listener are well familiar with. When someone says for instance that while trying to caution his or her ward that "Okro tree does not grow taller than the planter", the phrase is simple and apt. The audience is familiar with the concept "Okro" and of course he or she is aware that no matter how tall okro tree is, it can always be bent. This simply denotes that a child should always be respectful to his elders especially his parents. The language of proverb, like the language of some other aspects of oral literature, is very vivid and precise[9].

\section{Panegyrics}

This is a praise song usually sung by some gifted individuals at official functions in praise of some prominent people in order to get some financial gratifications from them. Chris Baldick in his Oxford Concise Dictionary of Literary Terms defines panegyrics as a public speech or written composition devoted to the prolonged, effusive praise of some person, group of people, or public body (eg. a government or army). In official gatherings like ofalla and occasions as such, minstrels take their percussions and stand at the entrance waiting for prominent and wealthy looking people. On sighting them, they begin to sing praise songs usually not previously composed. In such praise songs, the minstrels praise the people's imaginary achievements even when they never knew them. They would give them many beautiful and heroic names like "Omeluora, Ochiliozua, Ukpakanagbanaudumiri" among others all in a bid to be tipped.

The language of the Panegyrics according to Nkem Okoh, in Preface to Oral Literature, ranges between official and informal. The performers are talented and they know that they are only able to impress their target to tip them only when their performance appeals to them. Therefore, they play with dexterity in order to entice their target to bless them with their wealth. In other words, their ability to get more money depends to a great extent on their performance.

In order to perform well, Nnyagu in his article "The Nature of Oral Literature" maintain that the panegyrists must be mindful of their language. As it is the case with all aspects of literature, literary language is emotive, language of Panegyrics whether official or informal, is emotive. As an indispensable element of literature, the performer ensures that he uses such language apt with the occasion and such which will appeal to his target to tip him well. This is a fact because if the language of the panegyrist fails to appeal to the person he is addressing, he or she simply leaves him and goes his way or he or she may simply give him a peanut just for him to go his way. When the language appeals to him, he would allow the panegyrist to stay a longer time with him as he deliberately delays tipping him but through his body language, the panegyrist would understand that he is actually entertaining him and that his efforts would never be in vain. In most cases, the performers are hilarious; they use such languages that would make their subjects laugh and develop interest in whatever they talk about. Dull panegyrists who do not make use of exciting languages are always left with little or no cash at all while those who use the language well, punctuating it with apt proverbs go home at the end of the day happy because they are well tipped[10].

\section{CONCLUSION}

It is a fact undisputed that for one to understand the secrets of any art, one goes deep into the art. The researcher is aware of this fact and that is why he decided to dig deep to ascertain the language suitable for each of the various genres of oral literature. This aspect of literature seems to be going into extinction as people seem to be only interested in the modern arts only. However, concerned people who understand the need not to allow the art to die a natural death do what they can to resuscitate it. Some of these people, in a bid to keep oral literature alive, get it adulterated by presenting the art however they deem fit paying little or no attention to the traditional way the original art used to be rendered. It is not uncommon these days to hear folktale being performed by singers using virtually everything western such as guitar, piano, modern drum and especially the language. The listeners who knew the original tale now listen to the adulterated tale and find it difficult to believe that it is the same tale they knew. In their performance, the modern artists try to claim the ownership of the tales by trying to confuse the audience with the personal stylistics. It is not however, that each performer has no right to add whatever he or she deems necessary to make his or her art interesting and appealing but such should be subtly done so that the original beauty of the tale is not eluded. It is for this reason that the researcher has gone to the field to listen to modern artists perform. Many Ogene musicians perform popular folktales, myths, legends 
and many others. That is a good thing to do, at least, from their performance, children of these days who are no longer told tales would enjoy the popular tales but it appalls about how some if not all the modern performers have completely deviated from the normal convention of storytelling. As one who grew up in the village where the art was used in regular but appropriate occasions, the researcher is worried about the profuse deviation from the real thing by the modern performers.

\section{REFFERENCE}

1. Abrams, M. H. (2005). A Glossary of Literary Terms. Boston: Thomson Wadsworth.

2. Achebe, C. (1946). Arrow of God. London: Heinemann.

3. Akporobaro, F.B.O. (2006). Introduction to African Oral Literature. Ikeja: Princeton publishing company.

4. Baldick, C.(2004). Concise Dictionary of Literary Terms. New York: Oxford University Press.

5. Finnegan, R. (1970). Oral Literature in Africa. London: Oxford University Press.

6. Nnyagu, Uche. Kite and Chicken. Obosi: Pacific.

$7 . \quad$ _. (2008). Lizard and Chameleon. Obosi: Pacific.

$8 . \quad$ (2017). "The Nature of Oral Literature: Concepts and Genres" in Scholars Journal of Arts, Humanities and Social Sciences. (9A):1149-1155.

9. Ogbalu, F.C. (1984). Uyoko Mbem Igbo. Onitsha: University Publishing Co, 1984.

10. (1975). Mbediogu. Onitsha: University Press Co.

11. Okafor, J. N. J.(2010). The Big Fish. Onitsha: Africana-First.

12. Okoh, N. (2008). Preface to Oral Literature. Onitsha: Africana First Publishers.

13. Umeasiegbu, R.(1986). Anukili ugama. Enugu: Koruna Books. 